\section{AB0589 RELEVANCE OF B AND T CELL SUBSETS TO LUPUS FLARE IN KOREAN PATIENTS WITH SYSTEMIC LUPUS ERYTHEMATOSUS}

J.H. Koh ${ }^{1}$, N. Lee ${ }^{2}$, W.-U. Kim ${ }^{3} .{ }^{1}$ Division of Rheumatology, Department of Internal Medicine, Pusan National University Hospital, Pusan; ${ }^{2}$ Center for Integrative Rheumatoid Transcriptomics and Dynamics, The Catholic University of Korea; ${ }^{3}$ Division of Rheumatology, Department of Internal Medicine, Seoul St. Mary's hospital, the Catholic university of Korea, Seoul, Korea, Republic of Ireland

Background: Systemic lupus erythematosus (SLE) is a systemic autoimmune disease with heterogeneous clinical manifestations and is characterised with autoreactive $T$ cells and autoantibody overproduction by activated $B$ cells.

Objectives: The aims of this study were to characterised T-cell and B-cell subpopulation phenotype in Korean patients with SLE, and to elucidate the association between lymphocyte subpopulation and lupus activity.

Methods: We used multicolor flow cytometry to analyse subsets of peripheral blood B-cells (defined by CD19, IgD, CD27, and CD38) and T-cells (CD3, CD4, CD8, CD45RA, CCR7) in 26 patients with SLE and 22 age- and sex-matched healthy subjects. Baseline and 6 month follow-up SLE disease activity index (SLEDAI) was recorded, and SLEDAI score $>6$ was considered as lupus flare-up. Lymphocyte phenotype was also compared between stable disease and lupus flare-up.

Results: The number of $B$ cells and CD8 $+T$ cells were not different between SLE patients and healthy subjects; however, non-switched memory (NSwM) B cells was decreased in SLE patients. Double negative (DN) T cells, CD4 +T cells and its subset [naïve, central memory (CM), effector memory (EM) and terminally differentiated effector memory (TEMRA) cells] were decreased in SLE patients compared to healthy controls. Patients with lupus flare-up showed significantly decreased CD4 +and DN T cells, whereas CD4 +EM T cells were increased in patients with lupus flare up, compared to stable SLE. SLEDAI was correlated with DN T cells $(\rho=-0.728, p<0.001)$, CD $4+$ CM T cells $(\rho=-0.544, p=0.004), C D 4$ + EM T cells $(\rho=-0.697, p<0.001)$ and CD $8+E M$ T cells $(\rho=-0.408, p=0.039)$. Six (23\%) patients experienced lupus flare and a patient presented still high disease activity at 6 month follow-up visit. Interestingly, these patients showed the low number of DN T cells, CD4 +EM and TEMRA cells at baseline when they were stable.

Conclusions: Biassed differentiation of T-cells was associated with lupus flare and aggravation of SLE 6 months later. Understanding T cell subset enables accurate stratification of lupus flare-up and personalised approach.

\section{REFERENCES:}

[1] Nakayamada S, Iwata S, Tanaka Y. Relevance of lymphocyte subsets to B cell-targeted therapy in systemic lupus erythematosus. Int $\mathrm{J}$ Rheum Dis 2015;18:208-218.

[2] Anolik JH, Barnard J, Owen T, Zheng B, Kemshetti S, Looney RJ, et al. Delayed memory $B$ cell recovery in peripheral blood and lymphoid tissue in systemic lupus erythematosus after B cell depletion therapy. Arthritis Rheum 2007;56:3044-3056.

[3] Tsokos, G. C., M. S. Lo, P. C. Reis, and K. E. Sullivan. 2016. New insights into the immunopathogenesis of systemic lupus erythematosus. Nat Rev Rheumatol 12: 716-730.

Acknowledgements: We wish to thank Jihoon Kwon, the M.S. student for his excellent support.

Disclosure of Interest: None declared

DOI: 10.1136/annrheumdis-2018-eular.7514

\section{AB0590 A VALIDATION STUDY OF THE PREGNANCY MORBIDITY QUESTIONNAIRE(PMQ) IN WOMEN WITH ANTIPHOSPHOLIPID ANTIBODIES AND PREGNANCY MORBIDITY}

K. Schreiber ${ }^{1,2}$, S. Koder ${ }^{3}$, C. Ay ${ }^{3}$, I. Pabinger ${ }^{3}$, S. Jacobsen ${ }^{2}{ }^{1}$ Department of Thrombosis and Haemophilia, Guy's and St Thomas' Hospital, London, UK; ${ }^{2}$ Copenhagen Lupus and Vasculitis Clinic, Center for Rheumatology and Spine Diseases, Copenhagen University Hospital, Copenhagen, Denmark, ${ }^{3}$ Clinical Division of Haematology and Haemostaseology, Department of Medicine I, Medical University of Vienna, Vienna, Austria

Background: The presence of antiphospholipid antibodies (aPL) are associated with pregnancy complications. There is a lack of validated pregnancy questionnaires to assess previous pregnancy morbidity reliably in aPL positive patients. We therefore designed the pregnancy morbidity questionnaire (PMQ). Objectives: To validate the pregnancy morbidity questionnaire (PMQ) in the prospective Vienna Lupus Anticoagulant and Thrombosis Study (LATS) cohort. Methods: The Vienna Lupus Anticoagulant and Thrombosis Study (LATS) is an ongoing, single-centre, biobank-based, prospective observational cohort study enrolling patients (age $>18$ years) who are persistently positive for lupus anticoagulant (LA) (two positive tests at least 12 weeks apart) with or without a history of thrombosis or pregnancy complications ${ }^{1}$. The cohort currently consists of 150 patients (mean age: 41.3 years, female gender: $n=122(81.3 \%)$, history of thrombosis or pregnancy complications: $\mathrm{n}=111(74.0 \%))$. Of these 150 women, 15 were approached at their follow up visit and invited to fill out the PMQ. The PMQ consists eight questions outlined in table 2 .

Results: Twelve women agreed to participate, of whom nine had a previous history of pregnancy and/or pregnancy complications. Patient characteristics are shown in table 2. PMQ results are outlined in table 2.

Abstract AB0590 - Table 1

\begin{tabular}{|lc|}
\hline \multicolumn{2}{|c|}{ Patient Characteristics (N=9) } \\
\hline $\begin{array}{l}\text { Age at the time of questionnaire, mean (SD, range) } \\
\text { Years since last pregnancy, mean (SD, range) } \\
\text { Lupus anticoagulant positive only } \\
\text { Antiphospholipid syndrome }\end{array}$ & $58(+/-13.6,25-86)$ \\
\multicolumn{1}{|c|}{ Pregnancies (N=20) } & $35(+/-10,20-58)$ \\
& $5(25 \%)$ \\
\hline $\begin{array}{l}\text { Maternal age at pregnancy, mean (SD, range) } \\
\text { Live-birth rate }\end{array}$ & $2(10 \%)$ \\
Gestational age, weeks (SD, range) & $24.5(+/-4.3,18-33)$ \\
Birthweight, kg (SD, range) & $17 / 20(85 \%)$ \\
aPL related early pregnany loss (<10 weeks) & $34.8(+/-11,<10-24)$ \\
aPL related preterm delivery (<34 weeks) & $3.2(+/-0.5,2.2-4)$ \\
aPL related preterm delivery due to placental insufficiency & $2(10 \%)$ \\
Aspirin taken during pregnancy & $1(5 \%)$ \\
Heparin taken during pregnancy & $1(5 \%)$ \\
\hline Key: SD, standard deviation & $0(0 \%)$ \\
\hline
\end{tabular}

Abstract AB0590 - Table 2. Pregnancy questionnaire results

\begin{tabular}{lccc}
\hline & $\begin{array}{c}\text { Correct answer, } \\
\text { validated against cohort } \\
\text { info }\end{array}$ & $\begin{array}{c}\text { Detailed answer, but not } \\
\text { captured on cohort entry }\end{array}$ & $\begin{array}{c}\text { Incorrect } \\
\text { answer }\end{array}$ \\
\hline $\begin{array}{l}\text { Q1: Pregnancy date } \\
\text { Q2: Live birth }\end{array}$ & $20(100 \%)$ & $0 \%$ & $0 \%$ \\
$\begin{array}{l}\text { Q3: Gestational age at } \\
\text { delivery }\end{array}$ & $9(100 \%)$ & $0 \%$ & $0 \%$ \\
$\begin{array}{l}\text { Q4: Weight at delivery } \\
\text { Q5: aPL related }\end{array}$ & $1(45 \%)$ & $11(55 \%)$ & $0 \%$ \\
pregnancy & $18(90 \%)$ & $19(95 \%)$ & $0 \%$ \\
$\begin{array}{l}\text { complications } \\
\text { Q6: Aspirin during }\end{array}$ & $20(100 \%)$ & $0 \%$ & $2(10 \%)$ \\
$\begin{array}{l}\text { pregnancy } \\
\text { Q7: Heparin during } \\
\text { pregnancy }\end{array}$ & $20(100 \%)$ & $0 \%$ & $0 \%$ \\
$\begin{array}{l}\text { Q8: Other medications } \\
\text { during pregnancy }\end{array}$ & $20(100 \%)$ & $0 \%$ & $0 \%$ \\
\hline
\end{tabular}

Conclusions: Our aim was to validate the PMQ in the prospective Vienna Lupus Anticoagulant and Thrombosis Study (LATS) cohort. Patients were able to recall their pregnancy history in great detail over a period of more than three decades. Our PMQ may provide a tool to assess previous pregnancy morbidity in patients with antiphospholipid antibodies.

\section{REFERENCES:}

[1] Gebhart, J. P., F.; Koder, S.; Perkmann, T.; Quehenberger, P.; Zoghlami, C.; Ay, C.; Pabinger, I. Increased mortality in patients with the lupus anticoagulant: the Vienna Lupus Anticoagulant and Thrombosis Study (LATS). Blood 125, 3477-3483. http://dx.doi.org/10.1182/blood-2014-11-611129 (2015).

Disclosure of Interest: None declared DOI: 10.1136/annrheumdis-2018-eular.5791 